\title{
Distribution of dengue vectors in neighborhoods with different urbanization types of Manaus, state of Amazonas, Brazil
}

\author{
Claudia M Ríos-Velásquez/+ , Cláudia T Codeço*, Nildimar A Honório**, \\ Paulo S Sabroza***, Mônica Moresco, Ivana CL Cunha, Antônio Levino****, \\ Luciano M Toledo***, Sérgio LB Luz
}

Biodiversidade em Saúde ****Sóciodiversidade em Saúde, Centro de Pesquisa Leônidas \& Maria Deane-Fiocruz, Rua Teresina 476, 69057-070 Manaus, AM, Brasil *Programa de Computação Científica-Fiocruz, Rio de Janeiro, RJ, Brasil **Laboratório de Transmissores de Hematozoários, Instituto Oswaldo Cruz-Fiocruz, Rio de Janeiro, RJ, Brasil ***Escola Nacional de Saúde PúblicaFiocruz, Rio de Janeiro, RJ, Brasil

Aedes aegypti and Ae. albopictus are vectors of dengue viruses, which cause endemic disease in the city of Manaus, capital of the state of Amazonas, Brazil. More than 53 thousand cases have been registered in this city since the first epidemic in 1998. We evaluated the hypothesis that different ecological conditions result in different patterns of vector infestation in Manaus, by measuring the infestation level in four neighborhoods with different urbanization patterns, during the rainy (April), dry (August), and transitional (November) seasons. Ae. aegypti predominated throughout the study areas and sampling periods, representing $86 \%$ of all specimens collected in oviposition traps. High frequencies of houses positive for both species were observed in all studied sites, with Ae. aegypti present in more than $84 \%$ of the houses in all seasons. Ae. albopictus, on the other hand, showed more spatial and temporal variation in abundance. We found no association between infestation level and house traits. This study highlights the homogeneity of dengue vector distribution in Manaus.

Key words: Aedes aegypti - Aedes albopictus - dengue - Manaus

Epidemics of dengue fever have been recorded in Brazil since 1981-1982 (Siqueira et al. 2005), beginning a few years after the recolonization of the country by Aedes aegypti, its primary vector. At present, this dengue vector species is widespread in Brazil and transmits three of the four dengue virus serotypes (Nogueira et al. 2002). In Brazil, Ae albopictus is considered a potential vector of dengue, capable of transmitting these arboviruses and others under laboratory conditions (Schatzmayr 2000, Castro et al. 2004). This species is spreading throughout Brazil, causing concern (Santos 2003, Lourenço-de-Oliveira et al. 2004, Maciel-de-Freitas et al. 2006) because of its potential role as a vector of dengue and other arboviruses, as the yellow fever virus.

Manaus, capital of the state of Amazonas, currently with ca. 1,6 million inhabitants, is experiencing fast population growth (it doubled in the last 25 years). Amazonas was one of the last Brazilian states to be re-invaded by Ae. aegypti, in 1996 (Figueiredo et al. 2004), after its eradication in 1955 (Consoli \& Lourenço-de-Oliveira 1994). This city's first modern dengue epidemic occurred in 1998, when 13,873 cases, caused by DEN1 and DEN2 sorotypes, were recorded. Since then, dengue fever cases

Financial support: Fiocruz -PDTSP/Dengue (RDVE 04)

+Corresponding author: crios@amazonia.fiocruz.br

Received 22 February 2007

Accepted 26 June 2007 have occurred routinely, totaling more than 53 thousand cases to date (Susam 2002, Funasa 2003). DEN3 serotype has been recorded in Manaus since 2003 (Araújo et al. 2003).

Dengue fever in Manaus has assumed a seasonal pattern, peaking during the rainy months from February to May (FMTAM 2005). Sporadic human cases have being recorded during the other months. A high level of Ae. aegypti infestation in Manaus, together with the presence of three dengue serotypes, raises concerns regarding the risk of new epidemics and emphasizes the need for efficient entomological surveillance strategies for mosquito control.

Mosquito control in Manaus relies on pesticide applications to reduce adult and larval populations, campaigns for larval habitat elimination, fast entomological surveys during critical periods of dengue transmission, and public education. Entomological surveys based on the presence of Ae. aegypti immatures in containers (Focks \& Chadee 1997, Focks et al. 2000) continue to be the main surveillance tool in Manaus despite their inadequacy for dengue transmission risk assessment.

Ovitraps have been used for mosquito surveillance (Fay \& Perry 1965), dispersal and spatial pattern detection (Honório et al. 2003, Costa-Ribeiro et al. 2006), assessment of the impact of control measures (Mogi et al. 1990), and for detecting key containers for adult mosquito production (Souza-Santos 1999, Braga et al. 2000). The ovitrap is a sensitive, fast and cheap tool to detect Ae. aegypti (Fay $\&$ Eliason 1966). Studies in Brazil devoted to the evaluation of ovitraps for surveillance have shown that ovitraps may detect Ae. aegypti in geographical areas where larval surveys do not (Braga et al. 2000). 
In Manaus, rapid urbanization associated with irregular sanitation and water supply, combined with local topology (low lands), and climate (year-round high temperature, humidity, and a long and intensive rainy season) create a perfect setting for dengue vector proliferation (Pinheiro \& Tadei 2002). This work tests if neighborhoods with different urban conditions are associated with different levels of Ae. aegypti infestation in Manaus. Several authors have shown that the spatiotemporal distributions of Ae. aegypti and Ae. albopictus are associated with human activities, demographic density and climatic conditions (Kuno 1995, Alto \& Juliano 2001).

\section{MATERIALS AND METHODS}

Study area - The city of Manaus is located in the Northern Region of Brazil at the confluence of the Negro and Amazonas rivers ( $3^{\circ} 06^{\prime} \mathrm{S} ; 60^{\circ} 00^{\prime} \mathrm{W}$ ). The municipality is surrounded by the Amazonian forest and covers an area of $377,4 \mathrm{~km}^{2}$ divided into 56 neighborhoods. Manaus climate is "Ami" type (Köppen 1948), with the rainy season lasting from January and May and the dry season from June to September. A transitional period occurs between October and December.

Classification of Manaus neighborhoods - Manaus neighborhoods were classified into four types (Table I), using multivariate cluster analysis (Johnston 1978). Classification was based on socio-demographic-urban traits potentially associated with vector abundance (\% houses among buildings; $\%$ buildings with indoor access to piped water; $\%$ area covered with vegetation). The first two indicators were obtained from the 2000 census (IBGE 2000). The third was estimated from the analysis of Landsat satellite images using the Spring program (available in http://www.cbers.inpe.br/download/manaus.jpg) (Camara et al. 1996). This analysis generated four classes of neighborhoods: class A corresponded to well developed residential neighborhoods, with a high proportion of houses, adequate urban services, and low vegetation coverage. Type B corresponded to well developed residential areas as well, mostly with houses with adequate access to urban services and relatively high vegetation coverage (compared to A). Type $\mathrm{C}$ included areas mostly covered with buildings, adequate access to water and few green areas. Type D corresponded to recently settled areas, with poor access to urban services, and few green areas.

Entomological survey - For the entomological survey, we chose one neighborhood of each type: Chapada (type A), Coroado (type B), Flores (type C), and Tancredo Neves (type D) (Fig. 1). Since neighborhoods were large and heterogeneous, we restricted the survey to an area of approximately $800 \mathrm{~m}^{2}$ within each neighborhood. From street maps, we randomly sampled 50 pairs of coordinates censuring those less than $50 \mathrm{~m}$ apart. Householders were invited to participate in the study and, upon consent, were interviewed. We recorded information about the house (residential/commercial, system of waste collection and water supply, type of yard, house size) and the residents (number of inhabitants, schooling of the head of the family).

Three entomological surveys were carried out in 2004. One during the rainy season (April), one during the dry season (August), and one during the transition period (November-December/early rainy season, at the end of the dry season and beginning of rains) (Fig. 2). Two ovitraps were placed in the peridomiciliary environment of each house (where was easier to get permission from the residents), preferably in the garden or in a shady area (Dibo et al. 2005). An ovitrap consisted of a black plastic container filled with a mixture of water and hay infusion $(270 \mathrm{ml}: 30 \mathrm{ml})$, and a wooden stick $(15 \mathrm{~cm}$ $\times 2 \mathrm{~cm}$ ) to collect eggs. Houses were revisited every seven days, for three weeks. At each visit, larvae in the ovitraps were collected as well as the wooden sticks, and hay infusion replaced. In the laboratory, the larvae were identified using a key modified from Consoli and Lourenço-de-Oliveira (1994) and counted. The sticks were maintained in a humid box for one week, air-dried and their eggs counted. The wooden sticks positive for eggs were immersed in water and emerged larvae were reared to the fourth instar, identified and counted.

Data analysis - For the analysis, we calculated two indices: the proportion of surveyed houses with positive traps (where "positive" means at least one egg or larva of Ae. aegypti and/or Ae. albopictus during the 3week survey) and mean egg production per trap per week, calculated as the number of eggs collected per house

TABLE I

Classification of Manaus neighborhoods according to socio-demographic-urban variables associated with infestation risk

\begin{tabular}{lcccc}
\hline Neighborhood type & Type A & Type B & Type C & Type D \\
\hline Proportion of houses & +++ & +++ & ++ & ++ \\
$\%$ houses among buildings & +++ & ++ & ++ & ++ \\
$\%$ buildings with indoor access to water & +++ & +++ & ++ & + \\
$\%$ area covered with vegetation & + & +++ & + \\
\hline
\end{tabular}

+ low; ++ intermediate; +++ high.

Type A: developed and residential neighborhoods, with a high proportion of houses, adequate urban services and low vegetation coverage; Type B: residential areas, mostly with houses with adequate access to urban services and relatively high vegetation coverage; Type C: areas mostly covered with buildings, adequate access to water and few green areas; Type D: recently settled areas, with poor access to urban services, and few green areas. 


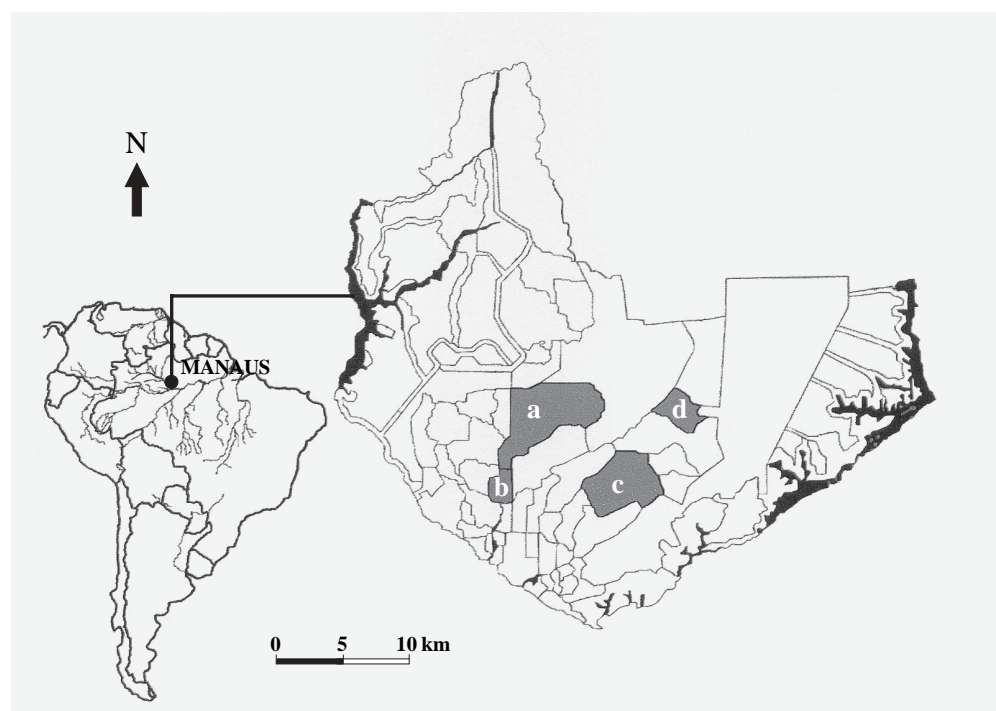

Fig. 1: map of Manaus showing the studied neighborhoods. a: Flores, b: Chapada, c: Coroado, d: Tancredo Neves.

divided by six ( 3 weeks $\times 2$ traps per house). Eventually, some ovitraps were lost. Missing ovitraps were discounted from the original number.

Logistic regression analysis was performed to test for association between the presence/absence of $A e$. aegypti (or Ae. albopictus) in each house (response variable) and site, season, and site vs season. Univariate and multivariate models (with and without interactions) were fitted to the data and the best model was chosen by comparing model deviances by Chi-square tests. For analysis of 'mean egg production', the same modeling procedure was applied, but using linear regression models, after $\log$ transformation of the response variable.

To test for possible associations between house traits and mosquito presence, we fit logistic regression models using presence/absence of Ae. aegypti (or Ae. albopictus) as response variable and house traits as covariates.

Pearson's and Spearman correlation tests were used to test for associations between Ae. aegypti or Ae. albopictus production (log-transformed). Only Pearson's tests are shown because of the similarity of the results. All analyses were performed using the software R 2.3.1 (R Development Core Team 2006).

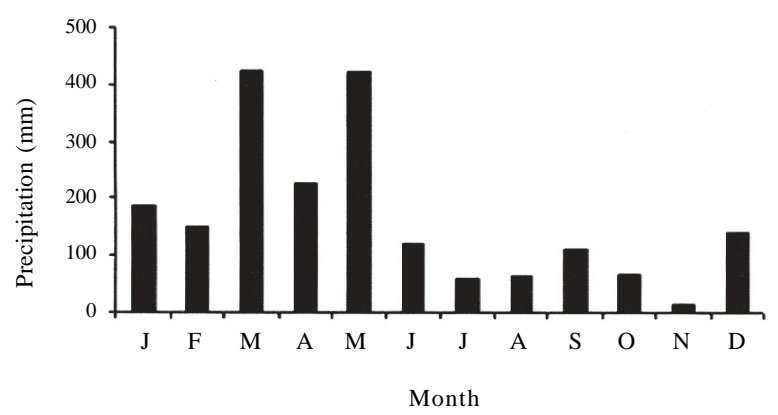

Fig. 2: monthly rainfall in the city of Manaus during 2004 (data provided by Instituto Nacional de Meteorologia).

\section{RESULTS}

Entomological survey - During the study 87,564 mosquito larvae were identified, $85.5 \%$ Ae. aegypti and $14.5 \%$ Ae. albopictus, the former species being more abundant in all sampling areas and seasons. A positive association was observed between Ae. albopictus and Ae. aegypti production, in all sites but Coroado (Chapada: Pearson's $r=0.31, \mathrm{df}=143, \mathrm{p}<0.001$; Flores: $\mathrm{r}=$ $0.36, \mathrm{df}=148, \mathrm{p}<0.001$; Tancredo: $\mathrm{r}=0.37, \mathrm{df}=148$, $\mathrm{p}<0.001$; Coroado: $\mathrm{r}=-0.05, \mathrm{df}=147, \mathrm{p}=0.5$ ). Houses positive for Ae. aegypti were very common in all sites and seasons. The lowest prevalence values were observed in the dry season (August) when Ae. aegypti was found in 84 to $90 \%$ of the houses (Fig. 3), while the highest values were found in November (transition period), with 94 to $98 \%$ of the houses positive. When evaluating for effects of site, season, and site $\mathrm{x}$ season (using logistic regression), the model with 'season' as response variable was the best. Using the driest month as reference (August), the odds of finding a positive trap in November was 4.8 (95\% IC:1.79-13, p < 0.001). April and August were not significantly different (Table II).

Ae. albopictus was less abundant in the rainy and dry seasons, increasing in the transition period (Fig. 4). This species showed variation among neighborhoods, being more abundant in Coroado, followed by Chapada. Tancredo Neves was the least infested. When fitting the logistic model, the effect of both season and site showed significance. The seasonal pattern of risk was very similar to that observed for Ae. aegypti: compared to the driest month (August), the odds of finding a positive trap in November was 4.6 (95\% IC:2.7-7.89; p < 0.001) (Table II). No significant difference again, between August and April.

Egg production of Ae. aegypti was homogeneous throughout the four sites, with a mean of 42 eggs per trap $(\max =376)$. April (the rainy month) produced the least number of eggs per trap $($ mean $=33$; std $=48)$ while 


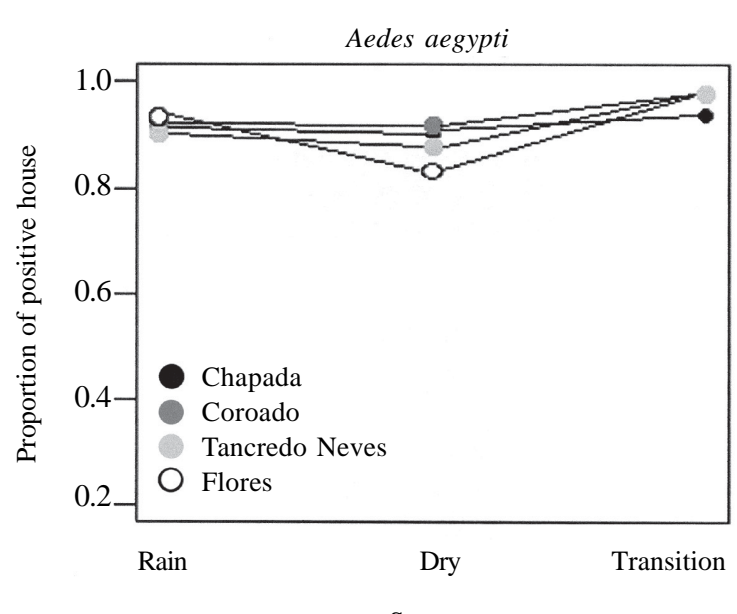

Season

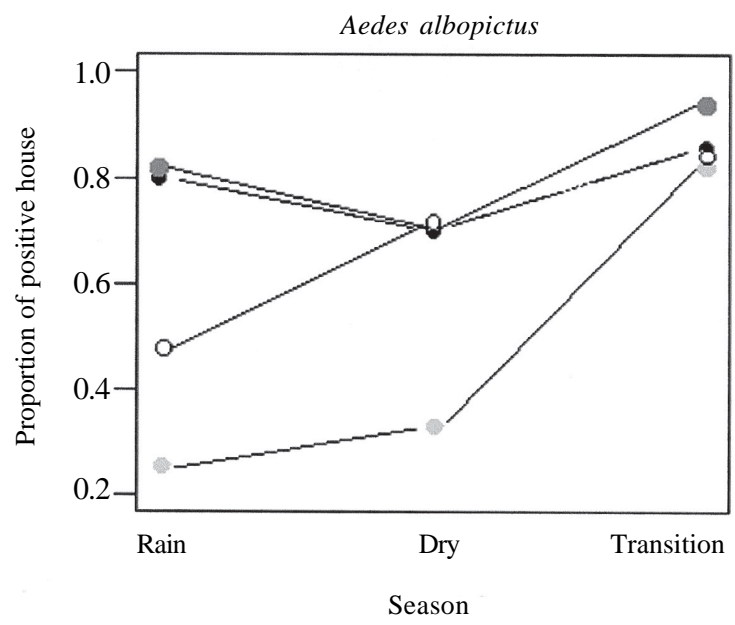

Fig. 3: proportion of surveyed houses positive for Ae. aegypti and Ae. albopictus in four neighborhoods of Manaus (Chapada, Coroado, Flores, Tancredo Neves), during the rainy, dry, and transition seasons of 2004. the other two seasons showed similar values [mean = 47; std $=46$ (Nov), std $=55$ (Aug) $]$. Among the three models tested for Ae. aegypti egg production, the best one had only the term 'season' (Table III). November was again, the most productive month.

We found no association between any house trait, obtained during the survey, and A. aegypti infestation: sewage system $\left(\chi^{2}=0.001\right.$, df $\left.=1, \mathrm{p}=0.975\right)$, water pipe $\left(\chi^{2}=2.05, \mathrm{df}=1, \mathrm{p}=0.15\right)$, type of courtyard $\left(\chi^{2}=\right.$ 0.042 , df $=2, \mathrm{p}=0.97)$, schooling of the family leader $\left(\chi^{2}=1.92\right.$, df $\left.=3, \mathrm{p}=0.59\right)$ (Table IV). When comparing the median number of residents and rooms between positive and negative houses, we found no significant difference (residents: Wilcoxon $\mathrm{W}=8778.5, \mathrm{p}=0.22$; rooms: Wilcoxon $\mathrm{W}=9171.5, \mathrm{p}=32$ ). Without significant effects, no further modeling was attempt. Regarding $A e$. albopictus, univariate analysis show significant effects of sewage and type of yard, but these effects vanished when neighborhood was taken into account (results not shown).

\section{DISCUSSION}

Manaus neighborhoods were classified into four types according to social and environmental characteristics potentially associated with Ae. aegypti infestation, nevertheless there were no significant differences among them in abundances of Ae. aegypti immatures. Ae. aegypti showed a wide and apparently uniform distribution across the city of Manaus, with high numbers in all surveyed areas during the three periods. We expected a higher abundance of Ae. aegypti in Tancredo Neves due to the large number of water reservoirs used for water storage. Although infestation was very high in Tancredo Neves, similar levels were also found in the other sites. At the local scale, we found no associations between house characteristics (such as sewage system, water pipes, kind of yard, schooling, number of residents, number of rooms), and the abundance of Ae. aegypti. Pinheiro and Tadei (2002), on the other hand, found

TABLE II

Results from the logistic model for the presence of Aedes aegypti or Ae. albopictus in traps, considering as potential predictors: site, season, and site vs season

\begin{tabular}{|c|c|c|c|c|}
\hline \multirow[b]{2}{*}{ Variable } & \multicolumn{4}{|c|}{ Ae. aegypti } \\
\hline & OR & $95 \% \mathrm{OR}$ & z-value & p-value \\
\hline Season August & 1 & & & \\
\hline Season April & 1.52 & $0.76-3.03$ & 1.202 & 0.229 \\
\hline \multirow[t]{2}{*}{ Season November } & 4.82 & $1.79-13.0$ & 3.108 & 0.001 \\
\hline & \multicolumn{4}{|c|}{ Ae. albopictus } \\
\hline Variable & OR & $95 \% \mathrm{OR}$ & z-value & $\mathrm{p}$-value \\
\hline Season August & 1 & & & \\
\hline Season April & 0.80 & $0.51-1.23$ & 2.684 & 0.31 \\
\hline Season November & 4.62 & $2.70-7.89$ & 5.59 & $<0.001$ \\
\hline Site Tancredo & 1 & & & \\
\hline Site Chapada & 6.11 & $3.49-10.69$ & 6.34 & $<0.001$ \\
\hline Site Coroado & 6.97 & $3.95-12.30$ & 6.71 & $<0.001$ \\
\hline Site Flores & 2.72 & $1.65-4.49$ & 3.91 & $<0.001$ \\
\hline
\end{tabular}

OR: odds ratio. 

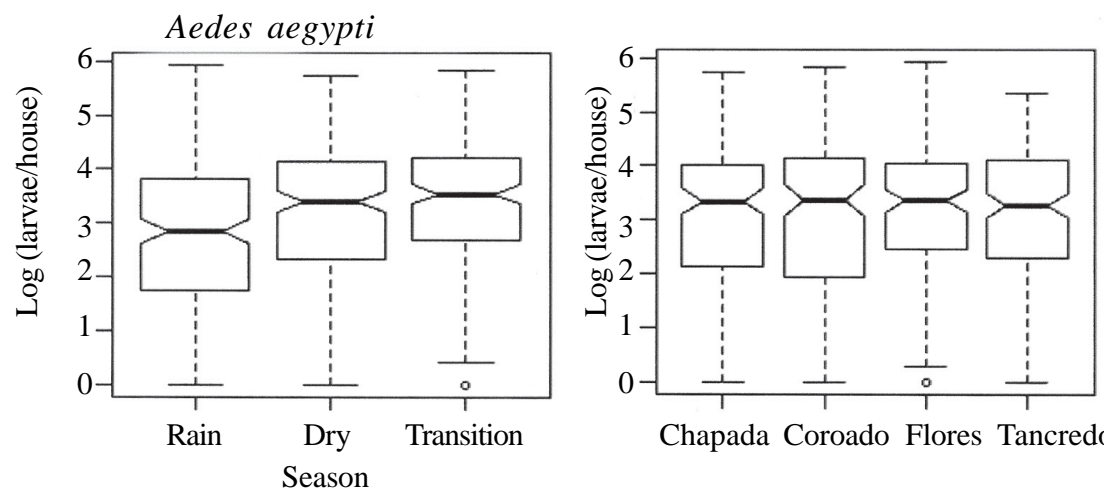

Chapada Coroado Flores Tancredo
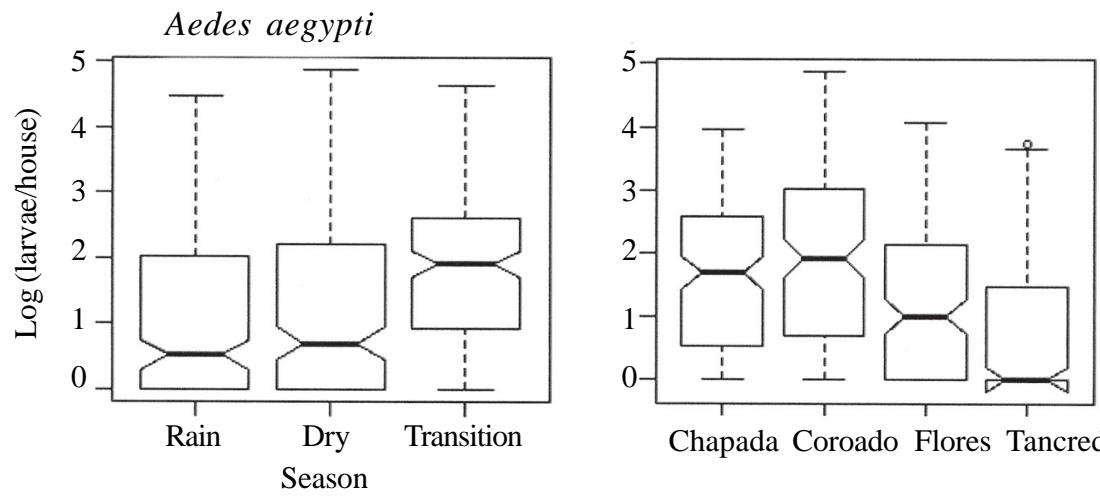

Chapada Coroado Flores Tancredo

Fig. 4: boxplot of week mean number of Ae. aegypti and Ae. albopictus larvae captured per house (log scale) stratified per season and per neighborhood in Manaus, 2004 (Notches indicate median 95\% confidence intervals).

TABLE III

Results from the linear model for the mean egg production of Aedes aegypti or Aedes albopictus per trap, considering as potential predictors: site, season, and site vs season

\begin{tabular}{lcccc}
\hline & \multicolumn{4}{c}{ Ae. aegypti $\left(R^{2}=0.06\right)$} \\
\cline { 2 - 5 } Variable & Estimate & $95 \% \mathrm{CI}$ & $\mathrm{t}$-value & $\mathrm{p}$-value \\
\hline Season April & -0.392 & {$[-.66,-.11]$} & -2.778 & 0.005 \\
Season November & 0.252 & {$[-.02, .53]$} & 1.78 & 0.07 \\
& & Ae. albopictus $\left(R^{2}=0.21\right)$ & $\mathrm{p}$-value \\
Variable & Estimate & $95 \% \mathrm{CI}$ & $\mathrm{t}$-value & 0.98 \\
Season April & 0.00 & {$[-.58, .33]$} & 0.02 & $<0.001$ \\
Season November & 1.35 & {$[-.16, .75]$} & 5.94 & $<0.001$ \\
Site Chapada & 1.23 & {$[.78,1.69]$} & 5.31 & $<0.001$ \\
Site Coroado & 1.29 & {$[.84,1.74]$} & 5.68 & $<0.001$ \\
Site Flores & 0.98 & {$[.53,1.42]$} & 4.29 & 0.0012 \\
Chapada $\times$ Nov & -1.05 & {$[-1.69,-0.41]$} & -3.2 & 0.033 \\
Coroado $\times$ Nov & -0.68 & {$[-1.32,-0.05]$} & -2.13 & 0.0001 \\
Flores $\times$ Nov & -1.23 & {$[-1.87,-0.6]$} & -3.83 & \\
\hline
\end{tabular}

higher infestation of Ae. aegypti in Manaus in neighborhoods with poorer social conditions and water reservoirs, owing to the paucity of piped water. These authors assessing all water containers showing potential for harbouring and breeding of Ae. aegypti in two different neighborhoods of Manaus, but the method to evaluate the social and water supply conditions was not explained. Maciel-de-Freitas et al (2007), evaluating pro- ductivity of containers in Rio de Janeiro, Brazil, found higher mean numbers of pupae per house in well infrastructured district than in a slum. All of these results must be considered with attention because there are many factors influencing the Ae. aegypti infestation indexes, and every place has its particular characteristics.

A homogeneous distribution of Ae. aegypti was also observed by Getis et al. (2003), in the Amazonian city 
TABLE IV

Characteristics of residents and houses in the neighborhoods surveyed

\begin{tabular}{lllll}
\hline Sampled neighborhoods & Chapada & Coroado & Flores & Tancredo Neves \\
\hline$\%$ with adequate sewage service & 62 & 50 & 30 & 36 \\
Piped water & 84 & 74 & 68 & 68 \\
Yard (with trees; cement; no) & $18 ; 50 ; 26$ & $48 ; 46 ; 4$ & $50 ; 44 ; 0$ & $84 ; 12 ; 0$ \\
No. rooms (median, min, max) & $5(2-22)$ & $5(1-10)$ & $6(2-16)$ & $4.5(2-10)$ \\
Residents/room (mean) & 0.84 & 1 & 0.88 & 1.36 \\
Schooling chief (median) & High school & High school & High school & Basic \\
$\%$ graduated & 18 & 8 & 12 & 0 \\
\hline
\end{tabular}

of Iquitos, Peru. This result may be explained by the relatively high availability of artificial containers throughout that city, high rainfall, and temperature. The climate in the Amazon region presents rather subtle variations. Although precipitation is lower during the dry season, it still is enough to maintain natural and artificial larval habitats. This pattern is distinct from other regions in Brazil, where greater numbers of Ae. aegypti are observed during the summer, when temperature and rainfall are high (Souza-Santos 1999, Glasser \& Gomes 2002, Honório et al. 2006).

We observed a slightly lower abundance of both species during the dry season compared to the rainy season, as found by Pinheiro and Tadei (2002) in Manaus and Mahadev et al. (2004) in India. These authors indicated April (the month with highest precipitation) as the month with highest abundance of Ae. aegypti and Ae. albopictus, but they did not assess the transitional period (November). This was the period when we observed a significant increase in the abundance of both species. In the transitional period, low precipitation is sufficient to maintain habitats and hatch eggs accumulated during the dry season. Although large number of dengue cases in Manaus has been observed in the rainy season, a considerable number of dengue cases has been reported in the transitional or dry seasons, which demonstrates endemic dengue transmission occurring the entire year (Siqueira et al. 2005, Pinheiro et al. 2005). The strong control measures against both immature and adult mosquito forms, applied in the city of Manaus by the Fundação Nacional de Saúde (Funasa), during the rainy season, could diminish the mosquito populations. Detailed studies about that fact must be done.

Ae. albopictus was found in all sites, although more abundantly in the "greener" neighborhoods. This species has colonized different areas in Manaus, including recent human settlements and totally urbanized areas (Fé et al. 2003, Sá 2004). The presence of houses with open yards, next to forest fragments, enhances risk for $A e$. albopictus (Passos et al. 2003, Lourenço-de-Oliveira et al. 2004, Mahadev et al. 2004, Maciel-de-Freitas et al. 2006), as in the Coroado neighborhood.

Although control strategies tend to be promoted during the rainy season, we suggest that control measures should consider the transitional period as a potential time for implementation.
In conclusion, our results point to the importance of the transition season as a period for vector surveillance and control. Our results also point to the potential benefit of using sentinel sites for vector surveillance in Manaus. Probably a sample of randomly chosen neighborhoods could be used as sentinel areas year-round, since all neighborhoods show similar infestation levels in any season. A survey with more neighborhoods should be done in the future to confirm these results.

\section{ACKNOWLEDGEMENTS}

To Alcinete Barbosa, Ricardo Mota, Almir Fontão, and Ciro Souza for support in field work. To Fernando Abad-Franch for important comments.

\section{REFERENCES}

Alto BW, Juliano AS 2001. Precipitation and temperature effects on populations of Aedes albopictus (Diptera: Culicidae): implications for range expansion. J Med Entomol 38: 646-656.

Araújo GCA, Travassos da Rosa ES, Vasconcelos HB, Nunes MRT, Carvalho CLC, Rodrigues SG, Cruz ACR, Vasconcelos P 2003. Sorotipos de dengue isolados no Instituto Evandro Chagas no ano de 2002. Rev Soc Bras Med Trop 36 (Supl. I): 16.

Braga IA, Gomes AC, Nelson M, Mello RC, Bergamaschi DN, Souza JMP 2000. Comparação entre pesquisa larvária e armadilha de oviposição, para detecção de Aedes aegypti. Rev Soc Bras Med Trop 33: 347-353.

Camara G, Souza RCM, Freitas UM, Garrido J 1996. SPRING: Integrating remote sensing and GIS by object-oriented data modeling. Computers \& Graphics 20: 395-403.

Castro MG, Nogueira RM, Schatzmayr HG, Miagostovich MP, Lourenço-de-Oliveira R 2004. Dengue virus detection by using reverse transcription-polymerase chain reaction in saliva and progeny of experimentally infected Aedes albopictus from Brazil. Mem Inst Oswaldo Cruz 99: 809-814.

Consoli RAGB, Lourenço-de-Oliveira R 1994. Principais Mosquitos de Importância Sanitária no Brasil, Fiocruz, Rio de Janiero, $225 \mathrm{pp}$.

Costa-Ribeiro MCV, Lourenço-de-Oliveira R, Failloux AB 2006. Higher genetic variation estimated by microsatellites compared to isoenzyme markers in Aedes aegypti from Rio de Janeiro. Mem Inst Oswaldo Cruz 101: 917-921.

Dibo MR, Chiaravalloti-Neto F, Battigaglia M, Mondini A, Favaro EA, Barbosa AAC, Glasser CM 2005.Identification of the best ovitrap installation sites for gravid Aedes (Stegomyia) 
aegypti in residences in Mirassol, state of São Paulo, Brazil. Mem Inst Oswaldo Cruz, 100: 339-343.

Fay RW, Eliason DA 1966. Preferred oviposition sites as a surveillance method for Aedes aegypti. Mosq News 26: 531-535.

Fay RW, Perry AS 1965. Laboratory studies of ovipositional preferences of Aedes aegypti. Mosq News 25: 276-281.

Fé NF, Barbosa MGV, Alecrim WD, Guerra MVF 2003. Registration of the occurrence of Aedes albopictus in an urban zone in Manaus, Amazonas, Brazil. Rev Saúde Pública 37: 1-4.

Figueiredo RMP, Thatcher BD, Lima ML, Almeida TC, Alecrim WD, Guerra MVF 2004. Doenças exantemáticas e primeira epidemia de dengue ocorrida em Manaus, Amazonas, no período de 1998-1999. Rev Soc Bras Med Trop 37: 476-479.

FMTAM-Fundação de Medicina Tropical do Amazonas 2005. Casos de dengue diagnosticados e notificados na FMTAM no período de 2004 e $1^{\circ}$ trimestre de/2005. Informe Epidemiológico $n^{\circ}$. 1/2005-FMT. Available: http://www.fmt.am.gov.br; access: 05/02/2007.

Focks DA, Chadee DD 1997. Pupal survey: an epidemiologically significant surveillance method for Aedes aegypti: an example using data from Trinidad. Am J Trop Med Hyg 56: 159-167.

Focks DA, Brenner RJ, Hayes J, Daniels E 2000. Transmission thresholds for dengue in terms of Aedes aegypti pupae per person with discussion of their utility in source reduction efforts. Am J Trop Med Hyg 62: 11-18.

Funasa-Fundação Nacional de Saúde 2003. Distribuição de casos confirmados, por Unidade Federada. Brasil, 1980-2000. Available: http://www.funasa.org; access: 05/02/2007.

Getis A, Morrison AC, Gray K, Scott TW 2003. Characteristics of the spatial pattern of the dengue vector, Aedes aegypti, in Iquitos, Peru. Am J Trop Med Hyg 69: 494-505.

Glasser CM, Gomes AC 2002. Clima e sobreposição da distribuição de Aedes aegypti e Aedes albopictus na infestação do estado de São Paulo. Rev Saúde Pública 36: 166-172.

Honório NA, Cabello PH, Codeço CT, Lourenço-de-Oliveira R 2006. Preliminary data on the performance of Aedes aegypti and Aedes albopictus immatures developing in water-filled tires in Rio de Janeiro. Mem Inst Oswaldo Cruz 101: 225-228.

Honório NA, Silva WC, Leite PJ, Gonçalves JM, Lounibos LP, Lourenço-de-Oliveira R 2003. Dispersal of Aedes aegypti and Aedes albopictus (Diptera: Culicidae) in an urban endemic dengue area in the state of Rio de Janeiro, Brazil. Mem Inst Oswaldo Cruz 98: 191-198.

IBGE-Instituto Brasileiro de Geografia e Estatística 2000. População residente, sexo e situação do domicílio, censo demográfico. Available: http://www.ibge.gov.br; access: 05/02/2007.

Johnston RJ 1978. Multivariate Statistical Analyses in Geography, Longman, NY, 280 pp.

Köppen NW 1948. Climatologia, con un Estudio de los Climas de la Tierra, Fondo Cultural Económico, México, 478 pp.

Kuno G 1995. Review of the factors modulating dengue transmission. Epidemiol Rev 17: 321-335.

Lourenço-de-Oliveira R, Castro MG, Braks MAH, Lounibus LP
2004. The invasion of urban forest by dengue vectors in Rio de Janeiro. J Vector Ecol 29: 94-100.

Maciel-de-Freitas R, Neto RB, Gonçalves JM, Codeço CT, Lourenço-de-Oliveira R 2006. Movement of dengue vectors between the human modified environment and an urban forest in Rio de Janeiro. J Med Entomol 43: 1112-1120.

Maciel-de-Freitas R, Marques WA, Peres RC, Cunha SP, Lourenço-de-Oliveira R 2007. Variation in Aedes aegypti (Diptera: Culicidae) container productivity in a slum and suburban district of Rio de Janeiro during dry and wet seasons. Mem Inst Oswaldo Cruz, 102: 489-496.

Mahadev PVM, Fulmali PV, Mishra AC 2004. A preliminary study of multilevel geographic distribution and prevalence of Aedes aegypti (Diptera: Culicidae) in the state of Goa, India. Indian J Med Res 120: 173-182.

Mogi M, Choochote W, Khamboonruang C, Suwanpanit P 1990. Applicability of presence-absence and sequential sampling for ovitrap surveillance of Aedes (Diptera: Culicidae) in Chiang Mai, northern Thailand. J Med Entomol 27: 509-514.

Nogueira RMR, Miagostovich MP, Schatzmayr HG 2002. Dengue virus in Brazil. Dengue Bull 26: 1-10.

Passos RA, Márquez GRAM, Voltolini JC, Condino MLF 2003. Dominância de Aedes aegypti sobre Aedes albopictus no litoral sudeste do Brasil. Rev Saúde Pública 37: 729-734.

Pinheiro VCS, Tadei PW 2002. Frequency, diversity, and productivity study on the Aedes aegypti most preferred containers in the city of Manaus, Amazonas, Brazil. Rev Inst Med Trop São Paulo 44: 245-250.

Pinheiro VCS, Tadei PW, Barros PMSS, Vasconcelos PFC, Cruz ACR 2005. Detection of dengue virus serotype 3 by reverse transcription polymerase chain reaction in Aedes aegypti (Diptera, Culicidae) captured in Manaus, Amazonas. Mem Inst Oswaldo Cruz 100: 833-839.

R Development Core Team 2006. R: a language and environment for statistical computing. R Foundation for Statistical Computing, Vienna, Austria. ISBN 3-900051-07-0, URL. Available: http://www.R-project.org; access: 2006.

Sá ELR 2004. Estudo das Áreas de Ocorrência e Criadouros Preferenciais de Aedes albopictus Skuse, 1984 (Diptera: Culicidae) em Manaus, Amazonas, Brasil, Inpa/Ufam, Manaus, $108 \mathrm{pp}$.

Santos RC 2003. Updating of the distribution of Aedes albopictus in Brazil (1997-2002). Rev Saúde Pública 37: 1-4.

Schatzmayr HG 2000. Dengue situation in Brazil by year 2000. Mem Inst Oswaldo Cruz 95(Suppl. 1): 179-181.

Siqueira JB, Martelli CMT, Maciel IJ, Coelho GE, Simplicio ACR, Hatch DL 2005. Dengue and dengue hemorrhagic fever, Brazil, 1981-2002. Emerg Infect Dis 11: 48-53.

Souza-Santos R 1999. Fatores associados à ocorrência de formas imaturas de Aedes aegypti na Ilha do Governador, Rio de Janeiro, Brasil. Rev Soc Bras Med Trop 32: 373-382.

Susam-Secretaria de Estado da Saúde do Amazonas 2002. Informe epidemiológico de dengue. Manaus: Departamento de Vigilância em Saúde, Ano II, no. 2. 
